\title{
Transapikální implantace aortální chlopně při řešení degenerativní aortální stenózy
}

\author{
Jan Harrer', Jan Vojáček', Josef Štásek², Jan Vojáček², Josef Bis², Tomáš Holubec¹, Miroslav Brtko', Pavel Polanský1 \\ ' Kardiochirurgická klinika, Kardiocentrum, Fakultní nemocnice Hradec Králové a Lékařská fakulta v Hradci Králové Univerzity \\ Karlovy $v$ Praze, \\ ${ }^{2}$ I. interní klinika, Fakultní nemocnice Hradec Králové a Lékařská fakulta v Hradci Králové Univerzity Karlovy v Praze a Kardio- \\ centrum, Fakultní nemocnice Hradec Králové, Česká republika
}

Harrer J, Vojáček J, Štásek J, et al. Transapikální implantace aortální chlopně při řešení degenerativní aortální stenózy. Cor Vasa 2010;52:325-331.

Úvod: V práci popisujeme naše první zkušenosti s katetrovou transapikální implantací aortální chlopenní bioprotézy Edwards Sapien. Metody a výsledky: Z 12 pacientů léčených transkatetrovou implantací aortální chlopně (TAVI) jsme doposud využili transapikální př́stupové cesty u pěti pacientů (sedmkrát byla provedena transfemorální implantace). Nikdo z pacientů v souvislosti s výkonem nezemřel. Periprocedurální a 30denní mortalita je v celém 12členném souboru nulová. Všichni nemocní léčení transapikální přístupovou cestou (TAP-AVI) přežívají a jejich klinický stav se zlepšil. Centrální regurgitace u jednoho z našich pacientů byla řešena strategií „valve-in-valve“. V článku popisujeme pracovní postup a též řešení komplikací, se kterými jsme se setkali.

Závěr: Transapikální implantace aortální chlopně je dnes již zavedenou léčebnou metodou s dobrými výsledky a prijiatelným rizikem. Naše iniciální zkušenost s touto technikou je příznivá.

Klíčová slova: Aortální stenóza - Chlopenní protéza - Transapikální implantace aortální chlopně

Harrer J, Vojáček J, Štásek J, et al. Transapical aortic valve implantation in patients with aortic valve stenosis. Cor Vasa 2010;52: $325-331$.

Introduction: Paper describes our initial experience with transapical aortic valve implantation (TAP-AVI) the Edwards Sapien system. Methods and results: Out of 12 patients treated with transcatheter aortic valve implantation (TAVI), we have so far used transapical aortic valve implantation (TAP-AVI) in five patients (transfemoral implantation was used in seven cases). Periprocedural and 30-day mortality was zero in the whole group of our 12 patients. All patients treated using TAP-AVI have survived with improved clinical status. Central regurgitation in one case was managed using the "valve-in-valve" strategy. We describe the procedure of implantation and possibility to manage complications we encountered.

Conclusion: Transapical aortic valve implantation is a safe therapeutical method with good results and acceptable risk. Our initial results of the transapical approach are encouraging.

Key words: Aortic stenosis - Valvular prosthesis - Transapical aortic valve implantation

Adresa: doc. MUDr. Jan Harrer, CSc., Kardiochirurgická klinika, Kardiocentrum, FN Hradec Králové a LF UK, Sokolská 583,50005 Hradec Králové, Česká republika, e-mail: harrer@fnhk.cz

\section{úvod}

Degenerativní aortální stenóza je v ekonomicky vyspělých zemích nejčastěji se vyskytující chlopenní vadou. Setkáváme se s ní především u starších nemocných. To souvisí s prodlužující se průměrnou délkou života.

$\mathrm{V}$ dnešní době nadále platí, že nejlepším způsobem řešení degenerativní aortální stenózy je náhrada aortální chlopně „klasickou“ chirurgickou přístupovou cestou s využitím mimotělního oběhu. Tento dnes standardní postup však představuje nemalou zátěž pro nemocného. Udává se, že až 30 \% nemocných s významnou degenerativní aortální stenózou není operováno pro př́liš vysoké riziko klasického chirurgického prŕstupu. Právě tito nemocní jsou pro transkatetrovou implantaci aortální chlopně (TAVI) indikováni. 
Díky velkému úsilí pracovní skupiny prof. Cribiera ${ }^{1}$ byl vyvinut implantační systém Edwards Sapien umožňující katetrovou implantaci.

Transkatetrové implantace aortální chlopně procházejí v poslední době bouřlivým rozvojem. Dnes jsou nejdelší zkušenosti s funkčností transkatetrově implantovaných chlopní již pět až šest let. Celkově bylo na světě katetrovou cestou implantováno již více než 10000 chlopní. Nejčastěji implantovanými systémy jsou systém Edwards Sapien a systém CoreValve. Kromě těchto dvou systémů, které se prosadily do humánní medicíny, se intenzivně pracuje na zhruba 20 dalších nových systémech katetrově implantovatelných chlopní.

Hlavní výhodou chlopenní protézy CoreValve je, že její polohu lze při neideálním místě ukládání při implantaci ještě korigovat vtažením do katetru a opětovným rozvinutím ve správné pozici. Další výhodou tohoto systému je, že umožňuje implantaci i do anulů $\geq 25 \mathrm{~mm}$.

Předností systému Edwards Sapien je, že je tento systém implantovatelný i transapikální cestou.

V Kardiocentru FN Hradec Králové byl program perkutánní transfemorální implantace chlopně Edwards Sapien zahájen v roce 2009. ${ }^{2}$ Šlo o první implantaci aortální chlopenní bioprotézy Edwards Sapien v České republice a později o první transapikální implantaci. ${ }^{3}$

\section{Soubor pacientů a metodika \\ Indikace}

K TAVI jsou indikováni nemocní se závažnou symptomatickou kalcifikovanou aortální stenózou (index plochy aortálního ústí $<0,6 \mathrm{~cm}^{2} / \mathrm{m}^{2}$ ), kteří jsou pro klasickou náhradu aortální chlopně kontraindikováni (porcelánová aorta), nebo nemocní s vysokým rizikem chirurgické léčby (logistické EuroSCORE > 20 \%) či s přítomností dalších komplikujících onemocnění, jako jsou těžká chronická obstrukční plicní nemoc, stavy po radiaci hrudníku a sterna, předchozí kardiochirurgický výkon u pacientů s funkčními koronárními štěpy.

Dalším rozumným kritériem je, aby předpokládaná délka akceptabilního života činila po prrípadné úspěšné TAVI alespoň dva roky.

Obecnými kontraindikacemi užití transfemorálního př́stupu u chlopní Edwards Sapien jsou:

1. přilišná tortuozita aorto-iliko-femorálního řečiště, která by bránila retrográdnímu zavedení katetru Retroflex, jímž je chlopeň dopravována do oblasti aortálního anulu, nebo by byla spojena s vysokou pravděpodobností poranění tepenného řečiště;

2. př́liš úzké lumen prrístupové tepny - chlopeň č. 23 se zavádí 22F instrumentáriem, které vyžaduje minimální průměr tepny $7 \mathrm{~mm}$, chlopeň č. 26 se zavádí $24 \mathrm{~F}$ instrumentáriem, jež vyžaduje minimální průměr tepny $8 \mathrm{~mm}$;

3. nález porcelánové aorty při CT angiografii - při tomto nálezu hrozí disekce nebo jiné poranění aorty při zavádění katetru Retroflex.
V případech, kdy je použití tohoto systému transfemorální cestou kontraindikováno, je možné použít transapikální př́stup $\mathrm{z}$ krátké anterolaterální thorakotomie nad srdečním hrotem.

Výhodou transapikální implantace chlopenní bioprotézy je malá zátěž pro nemocného. Vyhneme se tak klasickému prrístupu ze střední sternotomie, ale především nemusíme použít mimotělní oběh. $Z$ těchto důvodů si můžeme dovolit nabídnout tento postup i tam, kde by byla operace klasickou cestou přiliš riziková, nebo kde by byla dokonce kontraindikována.

Transapikální implantace aortální chlopně představuje poněkud vyšší zátěž pro nemocného než přístup transfemorální, který je možno provést i v lokální anestezii. Proto je transapikální přístup volen především tam, kde transfemorální implantaci provést nelze.

\section{Kontraindikace transapikální implantace aortální chlopně}

Šíře aortálního anulu > $25 \mathrm{~mm}$ je v současné době považována za kontraindikaci k výkonu. Další kontraindikací je nepř́itomnost kalcifikací v aortální chlopni a subvalvulární aortální stenóza. Kontraindikací je rovněž bikuspidální aortální chlopeň, intrakardiální trombus nebo vegetace, endokarditida, neléčená symptomatická ICHS či stav do jednoho měsíce od infarktu myokardu, ejekční frakce $<20 \%$, iktus v poslední době a hypertrofická obstrukční kardiomyopatie.

Z katetrizační implantace jsou vyloučeni nemocní s kalcifikacemi v oblasti ústí věnčitých tepen, které by mohly vést ke koronární obstrukci.

\section{Soubor pacientů}

V Kardiocentru LF UK a FN Hradec Králové byla dosud TAVI provedena u 12 pacientů. $Z$ tohoto souboru jsme využili transapikální př́stupové cesty u pěti pacientů (sedmkrát byla provedena transfemorální implantace).

Předoperační charakteristiku a anamnestické údaje shrnuje tabulka 1 . Z pětičlenného souboru byli dva muži a tř̀ ženy. Průměrný věk pacientů souboru byl 81,6 roku.

Implantace byly provedeny na modifikovaném hybridním operačním sále, kde bylo vše připraveno pro případ nutnosti konverze na klasickou náhradu aortální chlopně s užitím mimotělního oběhu.

\section{Postup při transapikální implantaci aortální chlopně Edwards Sapien}

Výkon musí provádět tým zkušených specialistů ve složení: kardiochirurg, invazivní kardiolog, echokardiografista, anesteziolog. Školení týmu je prováděno ve specializovaných centrech s možností sledování prováděného výkonu na pacientovi a s možností získat zkušenost na simulátoru, který byl za tímto účelem konstruován. První operace jsou prováděny za přítomnosti zkušeného proktora.

Pacienti podstupující TAVI absolvují předoperační anesteziologické vyšetření, při kterém je zhodnocen jejich 
Tabulka 1 Soubor operovaných - předoperační charakteristika a anamnestické údaje

\begin{tabular}{|c|c|c|c|c|c|c|c|c|c|c|c|c|c|c|c|c|c|c|c|}
\hline Pac. & Pohl. & $\begin{array}{l}\text { Věk } \\
\text { (roky) }\end{array}$ & BMI & $\begin{array}{l}\text { ES } \\
(\%)\end{array}$ & $\mathrm{DM}$ & $\mathrm{AH}$ & HLP & CMP & ICHDK & RI & IM & ICHS & AKB & $\mathrm{PCl}$ & FS & Nikotin & CHOPN & NYHA & $\begin{array}{c}\text { Pre-/ } \\
\text { synkopa }\end{array}$ \\
\hline 1 & muž & 81 & 23,4 & 10,7 & ne & ne & ano & ne & ne & ne & ne & ano & ne & ano & ne & ano & ne & III & ano \\
\hline 2 & žena & 74 & 20,8 & 18,7 & ne & ano & ano & ne & ne & ne & ano & ano & ne & ano & ano & ne & ne & III & ne \\
\hline 3 & muž & 86 & 23,7 & 21,3 & ano & ano & ano & ne & ano & ne & ano & ano & ano & ano & ano & ne & ne & III & ne \\
\hline 4 & žena & 85 & 32,8 & 10,7 & ne & ano & ne & ne & ne & ne & ne & ano & ne & ne & ne & ne & ne & III & ne \\
\hline 5 & žena & 82 & 25,7 & 29 & ano & ano & ano & ne & ne & ano & ano & ano & ne & ano & ano & ne & ne & III & ne \\
\hline
\end{tabular}

AH - arteriální hypertenze, AKB - chirurgická revaskularizace myokardu, BMI - body mass index, CMP - cévní mozková příhoda, ES - logistické EuroSCORE, FS fibrilace síní, HLP - hyperlipidemie/dyslipidemie, CHOPN - chronická obstrukční plicní nemoc, ICHDK - ischemická choroba dolních končetin, ICHS - ischemická choroba srdeční, IM - infarkt myokardu, PCI - perkutánní koronární intervence, RI - renální insuficience

aktuální zdravotní stav a před operačním výkonem je jim podána malá dávka benzodiazepinu a antihistaminika.

Po předání na operační sál a standardní př́pravě je pacientům zajištěn periferní žilní vstup a arteriální katetr. Úvod do celkové anestezie je veden opioidem, benzodiazepinem a periferním myorelaxanciem. Po úvodu do anestezie je zajištěn centrální žilní katetr, preferenčně do levé vnitřní jugulární žíly. Je zavedena nasogastrická sonda a močový katetr. Anestezie je vedena jako balancovaná, kombinací opioidu, periferního myorelaxancia a inhalačního anestetika. Hemodynamická stabilita je udržována titrací volumoterapie a vasoaktivní podpory. Rozsah monitorování odpovídá povaze kardiochirurgického výkonu.

Předoperační příprava je obdobná jako před klasickou kardiochirurgickou operací a na sále je k dispozici „stand-by“ mimotělní oběh. Na počátku operace jsou do femorální žíly a tepny zavedeny vodiče, po kterých lze v př́padě vynucené konverze na mimotělní oběh urychleně zavést perkutánní kanyly pro mimotělní oběh.

Dále je přes femorální tepnu retrográdně zaveden katetr „pigtail“ k aplikaci kontrastu do aortálního kořene.

Aortální chlopenní bioprotéza Edwards Sapien je balonexpandibilní biologická chlopeň z bovinního perikardu, která je upevněna $\mathrm{v}$ ocelovém stentu. $\mathrm{K}$ dispozici jsou v současnosti velikosti $23 \mathrm{~mm}$ pro velikost aortálního anulu $18-21 \mathrm{~mm}$ a $26 \mathrm{~mm}$ do aortálního anulu $22-24,5 \mathrm{~mm}$. Chlopeň je pomocí speciálního zařízení krimpována na $30 \mathrm{~mm}$ dlouhý balonek. Balonek s chlopní je zaváděn pomocí speciálního zaváděcího sheathu. Přesnou polohu srdečního hrotu je bezprostředně před operací vhodné upřesnit (označit pomocí transthorakální echokardiografie). Je provedena levostranná krátká přední thorakotomie v místě echokardiograficky označeného srdečního hrotu, obvykle v 5. nebo 6. mezižebří v rozsahu asi $10 \mathrm{~cm}$ (obrázek 1). Po otevření perikardu je $\mathrm{z}$ tohoto přístupu srdeční hrot velmi dobře přístupný. Na srdečním hrotu je tř̌eba určit pozici přední mezikomorové větve.

Před vlastní implantací je nutno zavést epimyokardiální elektrody a ověřit jejich správnou funkci. Těsně nad hrot a vlevo od přední mezikomorové tepny jsou do místa pozdějšího proniknutí do levé komory naloženy dva cirkulární stehy („purse-string suture“, Prolene 2-0, s velkou jehlou a podložkami). Alternativou jsou dva masivně naložené U-stehy s podložkou (obrázek 2). Stehy musejí být naloženy dostatečně hluboko, ale nesmějí procházet přes celou tlouštku myokardu levé srdeční komory.

Provedenou aortografií musejí být zobrazeny aortální sinusy a kalcifikované cípy aortální chlopně. Je nezbytné zvolit takovou skiaskopickou projekci, aby byly kalcifikované cípy a všechny aortální sinusy v jedné rovině. Před začátkem vlastní implantace chlopně je důležitá hemodynamická stabilita pacienta. Za tímto účelem jsou podávány tekutiny a př́padně i vasopresory tak, aby byl střední arteriální tlak udržován nad hodnotou $80 \mathrm{~mm} \mathrm{Hg}$. Implantace chlopně se provádí v celkové heparinizaci (heparin 100 j./kg i.v. požadovaná hodnota aktivovaného času srážení [ACT] je 250 vteřin).

Do srdečního hrotu je $\mathrm{v}$ místě cirkulárních stehů zavedena jehla a skrz ni měkký vodič, kterým se musí za skiaskopické kontroly antegrádně projít přes stenotickou aortální chlopeň.

Po vodiči pak zavádíme sheath rozměru 14 F. Měkký vodič je zaměněn za tuhý Amplatzův vodič („super stiff“,

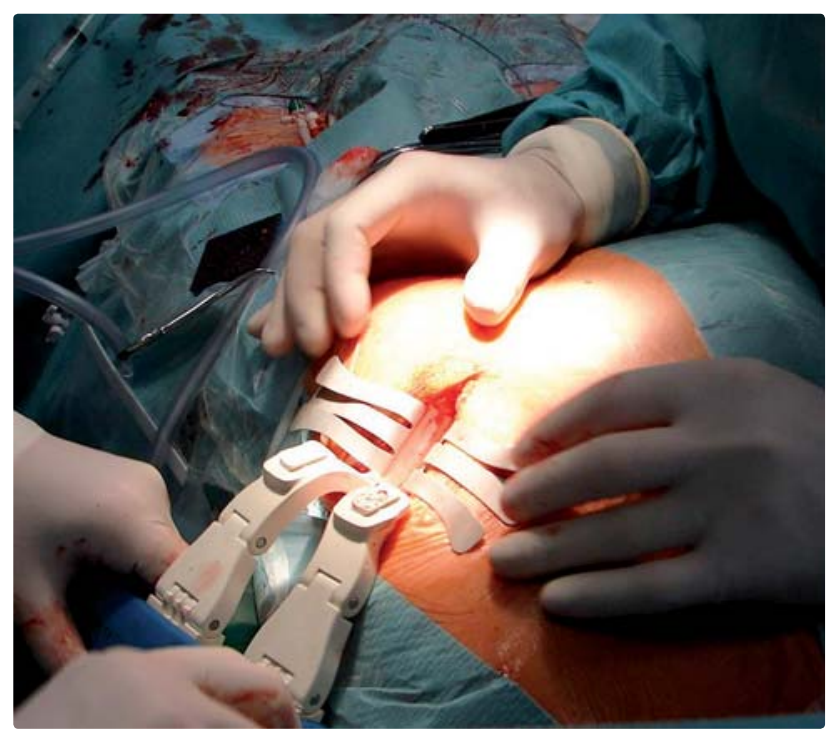

Obrázek 1 Operační př́stup z minithorakotomie 


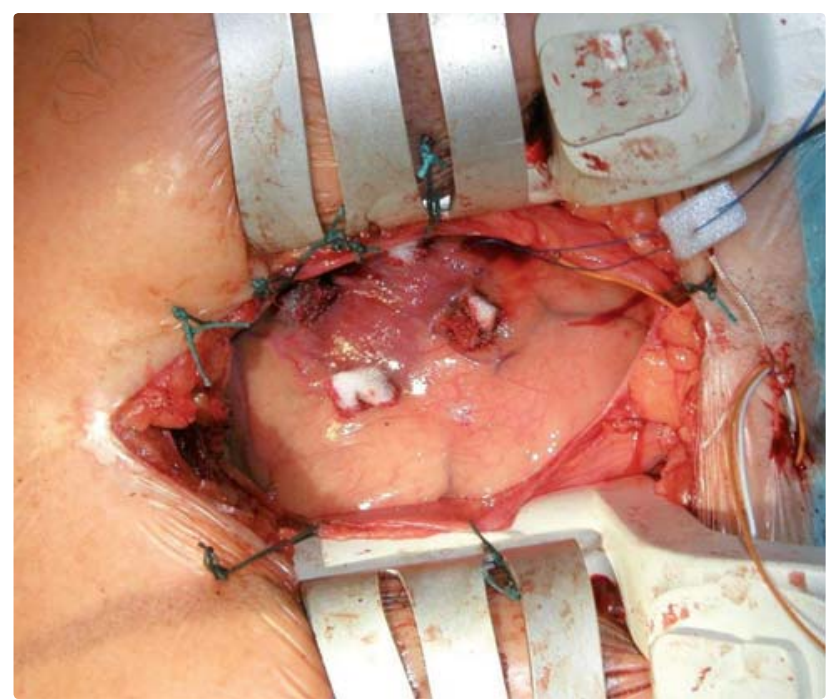

Obrázek 2 Obšité místo na srdečním hrotu pro zavedení implantačního systému

$260 \mathrm{~cm}$ ), který je umístěn přes oblouk do sestupné aorty s pomocí pravého Judkinsova katetru.

Dále je provedena balonková valvuloplastika pomocí balonku naplněného kontrastem zředěným 1:6 během pacemakerem navozené tachykardie (180-220/min) (obrázek 3 ). Cílem tohoto manévru je přechodně téměř zastavit cirkulaci, aby tím bylo dosaženo vyšší stability balonku při jeho rozepnutí. Ke stabilizaci nejlepší polohy balonku je vhodné přerušit po limitovanou dobu ventilaci.

Poté se vysune balonkový katetr i sheath a ponechá se jen vodič. Kontrola krvácení ze srdečního hrotu se v této fázi provádí tlakem prstu. Dále se po vodiči zavádí transapikální zaváděcí sheath (26F Ascendra sheath), jehož distální konec je umístěn asi $4-5 \mathrm{~cm}$ pod aortální chlopeň. Hloubka zavedení je vzhledem k epikardu asi 5-6 cm. Zavaděč sheathu je odstraněn a případné krvácení z hrotu je kontrolováno mírným dotažením založených obkružujících stehů.

$\mathrm{V}$ průběhu těchto příprav je vlastní chlopeň pomocí speciálního kompresního zařízení krimpována (složena a stlačena) na balonek. Před zavedením balonku do za- váděcího katetru se ještě zkontroluje správná orientace chlopně a zaváděcí katetr s chlopenní protézou se zasune do sheathu. Krátkým povolením kompresního šroubu je provedeno odvzdušnění systému.

Při vlastním zavádění chlopně je nejdůležitějším momentem přesné umístění chlopenního stentu. Orientujeme se podle umístění kalcifikátů v chlopni a podle polohy katetru „pigtail“, který byl retrográdně zaveden přes femorální tepnu až do Valsalvova sinu aortální chlopně.

Je velmi důležité respektovat odstupy koronárních tepen $\mathrm{z}$ hlediska vzdálenosti od anulu tak, aby nedošlo $\mathrm{k}$ jejich překrytí implantovanou chlopní. K upřesnění pozice se provádí angiografická kontrola. Optimální pozice k implantaci se dosáhne tehdy, jestliže se $50 \%$ délky stentu nachází nad rovinou středu chlopenních kalcifikátů a $50 \%$ délky stentu pod touto rovinou (obrázek 4).

Vlastní implantace chlopně se provádí kompletním naplněním balonku při komorové stimulaci 180-220/min (obrázky 5 a 6). Po desuflaci balonku a vypnutí pacemakeru se $\mathrm{v}$ průběhu několika vteřin obvykle stabilizují oběhové parametry. Střední arteriální tlak musí být co nejrychleji normalizován na hodnoty kolem $80 \mathrm{~mm}$ Hg. Normální tlak je v této fázi nutný ke správnému rozvinutí složených cípů chlopenní bioprotézy. Pomocí transezofageální echokardiografie (TEE) a aortografie se ověruje správná funkce chlopně. Po úspěšné implantaci je odstraněn zaváděcí sheath a vodič, zároveň jsou dotaženy předem naložené „purse-string“ stehy. Po odstranění vodiče se provádí konečná skiaskopická kontrola implantované chlopně. Protamin se podává v obvyklé dávce. Okraje perikardu sbližujeme, ale vždy necháváme $\mathrm{v}$ perikardiálním vaku malé okénko k prevenci tamponády. Do hrudní dutiny zavádíme hrudní drén pro odvedení vzduchu a krve z levé pleurální dutiny. Dále se provede standardní sešití operační rány. Za účelem analgezie je možno provést mezižeberní blokádu a infiltraci měkkých tkání dlouhodobě působícím lokálním anestetikem (0,5\% bupivacain $20 \mathrm{ml}$ ).

Po skončení operačního výkonu jsou pacienti v odeznívající anestezii předáváni $\mathrm{v}$ doprovodu anesteziologa na kardiochirurgickou JIP k následné pooperační péči a časné extubaci.
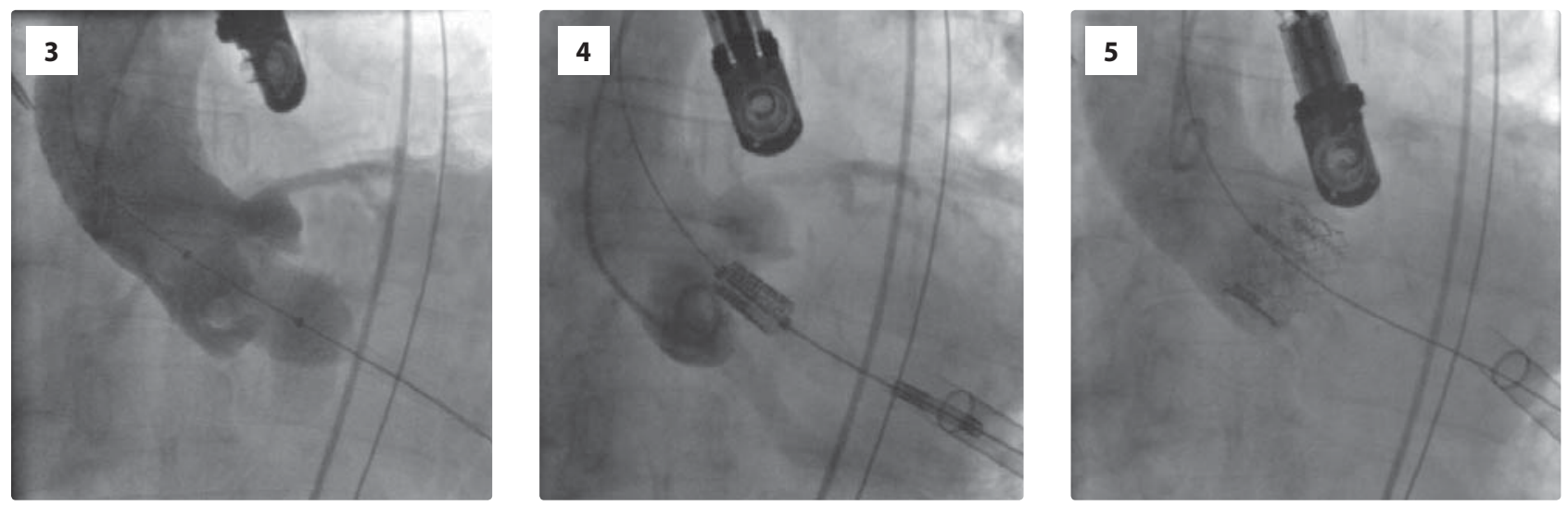

Obrázek 3 Insuflovaný balonek za účelem predilatace aortálního ústí

Obrázek 4 Optimální pozice chlopně těsně před implantací

Obrázek 5 Implantace chlopenní bioprotézy do aortálního ústí je provedena kompletním naplněním balonku 


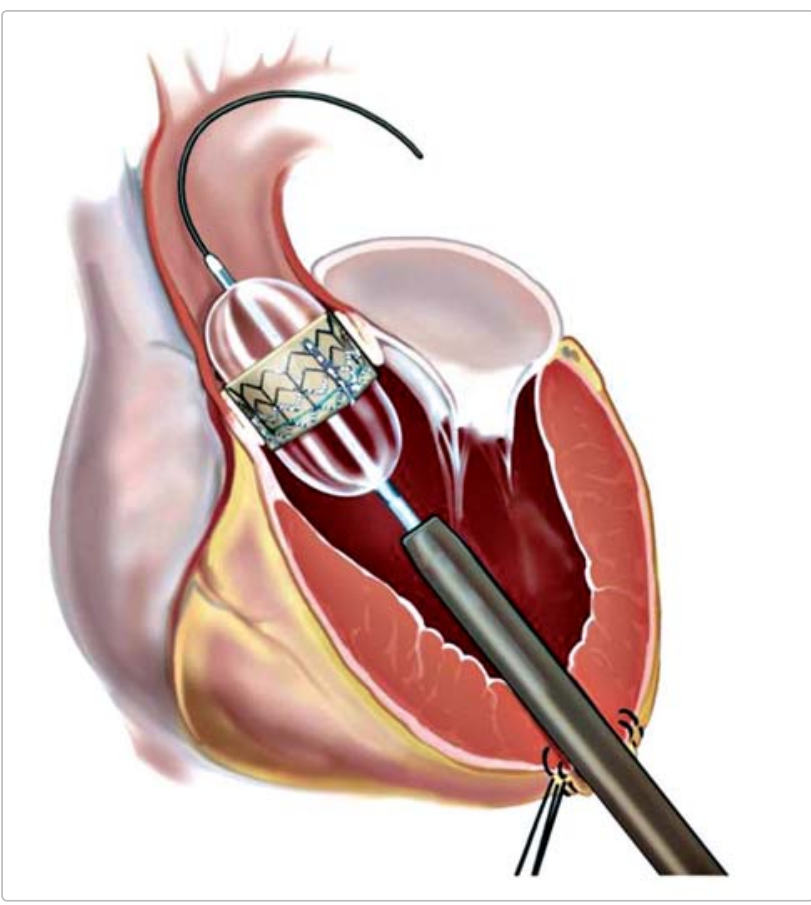

Obrázek 6 Schéma implantace aortální chlopně Edwards Sapien

\section{Možné chyby a nástrahy}

Při transkatetrové implantaci aortální chlopně mohou nastat obtížně předvídatelné okolnosti, které by př́padně vedly $\mathrm{k}$ destabilizaci cirkulace. Na ty musí být celý tým připraven. Destabilizace oběhových funkcí může nastat při balonkové valvuloplastice nebo při vlastní implantaci chlopně. Za těchto okolností je třeba použít diagnostickou a terapeutickou strategii zároveň. Při rozvratu cirkulace jsou přes předem zajištěné vstupy zavedeny transfemorální cestou kanyly, kterými je možno zahájit mimotělní oběh. Tím je převeden off-pump na on-pump výkon. Mezitím je nutno analyzovat přičinu rozvratu cirkulace, kterou umožní rozpoznat okamžitě provedená aortografie (možnost zjištění malpozice chlopenního implantátu či těžké centrální regurgitace při nedodilatované chlopni, případně uzávěr odstupu věnčité tepny vtlačeným kalcifikátem či okrajem stentu implantované chlopně). Pak je třeba uvažovat o angioplastice. Koronární obstrukce je naštěstí vzácnou komplikací. Její řešení (provedení bypassu nebo angioplastika se stentem) závisí na závažnosti stenózy a na riziku konkrétního terapeutického postupu.
Poměrně často se vyskytující paravalvulární leak bývá většinou malý a případná postdilatace bývá při správně volené velikosti chlopně zrrídka nutná.

Závažná dysfunkce chlopenní bioprotézy může nastat z malfunkce cípů vlastní protézy nebo při malpozici. Za těchto okolností je možno terapeuticky provést uložení další chlopně do nitra chlopně původní („valve-in-valve prosthesis“).

Při uvolnění chlopenní protézy s následnou embolizací je potřebná konverze na mimotělní oběh s chirurgickým řešením.

Krvácení z hrotu v místě zavádění implantačního sheathu vyžaduje další podložkovaný U-steh. K tomu je výhodnější medikamentózně snížit krevní tlak.

Disekce aorty či ruptura kořene aorty a s tím související krvácení je vzácnou komplikací vyžadující okamžité operační řešení s rekonstrukcí či náhradou kořene aorty.

\section{Výsledky}

Z pětičlenného souboru TAP-AVI (tabulka 2) proběhla u tří pacientů transapikální implantace zcela standardně a bez pozoruhodností.

Nestandardní průběh byl u 81letého muže, u kterého byla transapikální cestou implantována chlopeň Edwards Sapien velikosti $23 \mathrm{~mm}$ při rozměru aortálního anulu 21-22 mm. Vlastní výkon proběhl bez komplikací.

Při kontrolním echokardiografickém vyšetření byla zjištěna optimální poloha, avšak intermitentně docházelo $\mathrm{k}$ neúplnému rozvinutí jednoho z cípů aortální bioprotézy. Zhruba po třech měsících došlo $\mathrm{k}$ nárůstu dušnosti a při echokardiografické kontrole byla zjištěna progresivní dilatace levé komory srdeční. Situace byla řešena balonkovou dilatací, provedenou transfemorální př́istupovou cestou. Centrální regurgitace poté vymizela a další vývoj byl př́iznivý.

U jiného 86letého nemocného byla $\mathrm{z}$ důvodu neideální pozice implantované chlopně s následnou intravalvulární regurgitací provedena implantace další chlopenní protézy („valve-in-valve“). Intravalvulární regurgitace poté vymizela.

Při pooperačních kontrolách s odstupem 1-11 měsíců od operace (tabulka 3) jsou všichni pacienti klinicky zlepšeni (NYHA I-II). Kontrolní echokardiografické vyšetření hodnotilo paravalvulární regurgitaci (1.-4. stupeň) jednou jako stopovou, jednou jako 1 . stupně, třikrát jako 2. stupně.

Tabulka 2 Předoperační echokardiografické údaje

\begin{tabular}{|c|c|c|c|c|c|c|c|}
\hline Pacient & $\begin{array}{c}P G_{\max } / P G_{\text {mean }} \\
(\mathrm{mm} \mathrm{Hg})\end{array}$ & $\begin{array}{c}\text { AVAI } \\
\left(\mathrm{cm}^{2} / \mathrm{m}^{2}\right)\end{array}$ & $\begin{array}{c}\text { Al } \\
\text { (stupeň 1-4) }\end{array}$ & $\begin{array}{c}\text { MI } \\
\text { (stupeň 1-4) }\end{array}$ & $\begin{array}{c}\text { TI } \\
\text { (stupeň 1-4) }\end{array}$ & $\mathrm{PH}$ & EF (\%) \\
\hline 1 & $98 / 61$ & 0,37 & 2 & 2 & 2 & významná & 50 \\
\hline 2 & $130 / 84$ & 0,29 & stopová & 2 & 2 & významná & 70 \\
\hline 3 & $95 / 58$ & 0,34 & 1 & 2 & 0 & střední & 70 \\
\hline 4 & $88 / 53$ & 0,32 & 2 & 1 & 1 & mírná & 75 \\
\hline 5 & $110 / 60$ & 0,21 & 2 & 3 & 3 & významná & 50-55 \\
\hline
\end{tabular}




\section{Diskuse}

$\mathrm{V}$ průběhu 20 let vývoje $\mathrm{v}$ oblasti TAVI došlo $\mathrm{k}$ velkému a obdivuhodnému rozvoji celé technologie. Přesto i na současné úrovni jde o výkon mající svá úskalí. Ta souvisí jednak s vlastní technologií (tuhost a šírka implantačního zařízení, ukotvení chlopenní protézy radiálním tlakem $\mathrm{v}$ oblasti vysokotlakého systému s velkými mechanickými nároky). Úskalí rovněž souvisí s vlastnostmi a limity tkání (možnost ruptury či disekce kořene aorty). Výskyt kalcifikací v aortální chlopni a jejich rozložení hraje také významnou roli v posouzení indikace $\mathrm{k}$ TAVI. Rovněž je velmi důležité posouzení vztahu odstupu věnčitých tepen ke kalcifikátům a k morfologii cípů aortální chlopně.

Z uvedených dat plyne, že i na dnešní úrovni vývoje technologie TAVI má výkon nemalé riziko. Vývoj technologie však pokračuje dále.

V poslední době se též uplatňují počítačové programy usnadňující interpretaci skiaskopického obrazu v oblasti kořene aorty při vlastní implantaci.

Další otázkou, na kterou zatím máme jen částečnou odpověd', je doba funkčnosti implantované protézy. Dosavadní (až šestileté) zkušenosti a interpretace zkušeností z oblasti klasických stentovaných bioprotéz jsou př́íznivé. Limity v přežívání jsou dnes dány především biologickým potenciálem velmi rizikových pacientů, pro které je metoda určena. Je však jistě záležitostí nepř́liš vzdálené budoucnosti, že se indikace pro TAVI budou stále rozšiřovat do mladších věkových kategorií.

Ye a spol. ${ }^{4}$ publikovali jednoroční sledování souboru 26 nemocných po transapikální implantaci aortální chlopně. Z jeho souboru zemřelo do 30 dnů od výkonu šest nemocných $(23 \%)$ a po jednom roce ze souboru přežívá převážně s významným klinickým zlepšením 17 nemocných (65 \%). Ze závažných komplikací se autoři setkali jednou s perioperačním úmrtím v důsledku uzávěru levé koronární tepny kalcifikátem z chlopně. U tohoto nemocného bylo zároveň problémem krvácení ze srdečního hrotu. U čtyř pacientů ze souboru byla provedena redilatace implantované chlopně pro středně závažnou paravalvulární regurgitaci (třikrát $\mathrm{z}$ toho došlo ke zmenšení regurgitace).
Zierer a spol. ${ }^{5}$ udávají zkušenost s transapikální implantací aortální chlopenní protézy rovněž u 26 nemocných. Do 30 dnů od výkonu zemřeli čtyři nemocní (15\%). Jeden pacient zemřel na následky perforace pravé komory a jeden na následky disekce aortálního kořene. U jeho souboru byla dvakrát nutná konverze na mimotělní oběh. Parciální obstrukce kmene levé koronární tepny si dvakrát vyžádala angioplastiku s implantací stentu.

Tentýž autor ${ }^{6}$ ve své nerandomizované studii porovnával transapikální implantaci aortální chlopně (21 pacientů) s chirurgickou implantací z parciální sternotomie (30 pacientů). Při porovnání obou souborů zjistil, že u transapikální implantace byla doba provádění výkonu významně kratší. Zároveň byla kratší doba pooperační umělé ventilace, doba pobytu na jednotce intenzivní péče a doba hospitalizace. Třicetidenní mortalita byla u transapikální implantace vyšší (14\%) ve srovnání s chirurgickou náhradou (10\%). Zierer a spol. uzavírají, že transapikální implantace představuje menší zátěž, z čehož plyne rychlejší zotavení pacientů po operaci. Mortalita a morbidita se u souborů prríliš neliší.

Skupina expertů ${ }^{7}$ zastupujících European Association of Cardio-Thoracic Surgery a European Society of Cardiology hodnotí TAVI jako vhodnou pro nemocné s vysokým operačním rizikem a nemocné s kontraindikací klasického operačního výkonu. Výsledky při sledování do dvou let jsou celkem prríznivé. Dlouhodobé výsledky však zůstávají otázkou. Současnou dobu hodnotí jako období vyhodnocování a opatrné komercionalizace.

Walther a spol. ${ }^{8}$ udávají, že při transapikální implantaci aortální chlopenní protézy může být její uložení přesnější než při transfemorálním přístupu.

Doposud nemáme $\mathrm{k}$ dispozici žádná data $\mathrm{z}$ randomizovaných studií, která by porovnávala trasapikální implantaci s klasickou chirurgickou náhradou chlopně. Poznatky můžeme čerpat pouze ze dvou registrů - REVIVAL II (40 pacientů), TRAVERCE (168 pacientů). ${ }^{9}$ Výkon byl prováděn u pacientů s logistickým EuroSCORE 27-36 \%. Periprocedurální úspěšnost se v těchto registrech pohybovala mezi 88 a $93 \%$, konverze na sternotomii byla provedena v $7 \%$, 30denní mortalita byla $13-15 \%$ a dvouleté přežití 60-70\%. Periprocedurální mozková příhoda se vyskytla

Tabulka 3 Perioperační a pooperační komplikace

\begin{tabular}{|c|c|c|c|c|c|c|c|c|c|}
\hline Pacient & $\begin{array}{l}\text { Velikost chlopně } \\
\text { (mm) }\end{array}$ & Komplikace & $\begin{array}{c}\text { Kontrola } \\
\text { za x měsíců }\end{array}$ & NYHA & $\begin{array}{c}\mathrm{PG}_{\text {max }} / \mathrm{PG}_{\text {mean }} \\
(\mathrm{mm} \mathrm{Hg})\end{array}$ & $\begin{array}{c}\mathrm{Al} \\
\text { (stupeň 1-4) }\end{array}$ & $\begin{array}{c}\text { MI } \\
\text { (stupeň 1-4) }\end{array}$ & $\begin{array}{c}\text { TI } \\
\text { (stupeň 1-4) }\end{array}$ & EF (\%) \\
\hline 1 & 23 & ano* & 11 & I & $39 / 19$ & $2 * * *$ & 1 & 1 & $50-60$ \\
\hline 2 & 23 & ne & 11 & I & $36 / 17$ & stopová*** & 2 & 1 & $65-70$ \\
\hline 3 & 23 & ano** & 10 & II & $37 / 18$ & $2^{* * *}$ & 1 & 1 & $60-65$ \\
\hline 4 & 23 & ne & 3 & 1 & $19 / 11$ & $1^{* * *}$ & stopová & stopová & 70 \\
\hline 5 & 23 & ne & 1 & $\|$ & $21 / 10$ & $2^{* * *}$ & 2 & neuvedena & 70 \\
\hline
\end{tabular}


u $3 \%$, infarkt myokardu u $1 \%$, srdeční selhání u $5 \%$ nemocných. U $6 \%$ bylo nutné implantovat kardiostimulátor pro AV blok. Z dostupných dat je také zřejmé, že se výsledky v obou registrech v průběhu učicí křivky výrazně zlepšovaly. Transapikální implantace má tedy zatím vyšší 30denní mortalitu a obdobný výskyt periprocedurálních komplikací ve srovnání s klasickou náhradou aortální chlopně. Musíme si však uvědomit, o jak rizikovou skupinu pacientů jde (viz EuroSCORE).

$\mathrm{V}$ dnešní době se můžeme setkat i s názorem, že v budoucnu nebude transapikální prrístupová cesta potřebná. Tento argument stojí na předpokladu, že tam, kde jsou nepřijatelné podmínky pro transfemorální prrístup především $\mathrm{z}$ důvodu nevhodnosti pánevního tepenného řečiště (nedostatečný průsvit, sklerotické pláty, aneurysmata, tortuozity), se může použít cesta zavádění přes axilární tepnu. Je však třeba poukázat na to, že zatím je transaxilární přístupová cesta „off-label“, i když v budoucnu se jistě bude používat. Transaxilární př́ístup má však rovněž své kontraindikace (sklerotické změny axilární tepny, sklerotické změny $\mathrm{v}$ ascendentní aortě s vyšším rizikem iktu, stav po chirurgické revaskularizaci s funkčním mamarokoronárním bypassem). Největší zkušenosti s přístupem přes axilární tepnu mají v Royal Brompton \& Harefield NHS Foundation Trust. ${ }^{10}$

$\mathrm{Na}$ podkladě našich počátečních zkušeností s TAP-AVI můžeme konstatovat, že jde o slibnou metodu. Další hodnoticí studie, především z hlediska dlouhodobějších výsledků, jsou však žádoucí.

Bleizifferová a spol. ${ }^{11}$ udávají, že při porovnání transapikální implantace aortální chlopně ( $\mathrm{n}=50)$ s transfemorální prýstupovou cestou $(n=153)$ měli u transapikálního př́stupu 30denní mortalitu poněkud nižší (8,3\%) než u transfemorálního př́stupu (11,2\%).

Z pracovišst v České republice má s metodou největší zkušenost IKEM Praha. Želízko a spol. ${ }^{12}$ udávají výbornou zkušenost s perkutánní implantací aortální chlopně u 21 pacientů (systém CoreValve Revalving). Třicetidenní mortalita celého souboru byla nulová.

\section{Závěr}

Transapikální implantace aortální chlopenní protézy je nově zavedeným, minimálně invazivním postupem. Minimalizace zátěže spočívá ve vyhnutí se mimotělnímu oběhu a srdeční zástavě i v miniinvazivní př́ístupové cestě krátkou thorakotomií.

Výhodou transapikálního př́stupu je minimalizace rizika embolického iktu, nebot’ nedochází k manévrování instrumentáriem ve vzestupné aortě a v aortálním oblouku. Není závislost na průchodnosti pánevních tepen, a tudíž průměr zaváděcího zařízení nehraje významnější roli.
Nevýhodou je nutná minithorakotomie, která představuje určitou zátěž, zvláště pro pacienty s poruchou respiračních funkcí. V budoucnu však lze předpokládat zcela endoskopický přístup. Transapikální implantace aortální chlopně je metodou, která se neustále vyvíjí. U této metody je důležitá týmová spolupráce kardiochirurgů, kardiologů, anesteziologů a dalších specialistů.

Při této příležitosti je však potřeba zdưraznit, že zlatým standardem zůstává chirurgická náhrada aortální chlopně, a ta bude i nadále hlavní metodou při léčbě těžkého degenerativního postižení aortální chlopně. Pro vysoce rizikové symptomatické pacienty predstavuje TAP-AVI alternativu k prognosticky nevýhodnému konzervativnímu postupu.

Naše zatím skromné zkušenosti s TAP-AVI jsou slibné. Soubor dosud léčených pacientů bude dále sledován a analyzován.

\section{Literatura}

1. Cribier A, Eltchaninoff $H$, Tron $C$, et al. Early experience with percutaneous transcatheter implantation of heart valve prosthesis for the treatment of end-stage inoperable patients with calcific aortic stenosis. J Am Coll Cardiol 2004;43:698-703.

2. Štásek J, Vojáček J, Bis J, et al. První zkušenost s perkutánní transfemorální implantací chlopně Edwards SAPIEN ${ }^{\left({ }^{\mathrm{T}}\right)}$. Interv Akut Kardiol 2009;8:47-51.

3. Harrer J, Vojáček J, Štásek J, et al. První zkušenosti s transapikální implantací chlopně u nemocných s aortální stenózou. Interv Akut Kardiol 2009;8:100-104.

4. Ye J, Cheung A, Liechtenstein V, et al. Transapical transcatheter aortic valve implantation: 1-year outcome in 26 patients. J Thorac Cardiovasc Surg 2008;137:167-173.

5. Zierer A, Wimmer-Greinecker G, Martens S, et al. The transapical approach for aortic valve implantation. J Thorac Cardiovasc Surg 2008;136:948-953.

6. Zierer A, Wimmer-Greinecker G, Martens S, et al. Is transapical aortic valve implantation really less invasive than minimally invasive aortic valve replacement? J Thorac Cardiovasc Surg 2009;138:1067-1072.

7. Vahanian A, Alfieri OR, Al-Attar N, et al. Transcatheter valve implantation for patients with aortic stenosis: a position statement from the European Association of Cardio-Thoracic Surgery (EACTS) and the European Society of Cardiology (ESC), in collaboration with the European Association of Percutaneous Cardiovascular Interventions (EAPCI). Eurointervention 2008;4:193-199.

8. Walther T, Dewey T, Borger M, et al. Transapical aortic valve implantation: step by step. Ann Thorac Surg 2009;87:276-283.

9. Walther T, Simon P, Dewey T, et al. Transapical minimally invasive aortic valve implantation: multicenter experience. Circulation 2007;116(11 Suppl): I240-I245.

10. Asgar A, Mullen M, Delahunty N, et al. Transcatheter aortic valve intervention through the axillary artery for the treatment of severe aortic stenosis. J Thorac Cardiovasc Surg 2009;137:773-775.

11. Bleiziffer $S$, Ruge $H$, Mazzitelli $D$, et al. Survival after transapical and transfemoral aortic valve implantation: Talking about two different patient populations. J Thorac Cardiovasc Surg 2009;138:1073-1080.

12. Želízko M, Malý J, Janek B, et al. Perkutánní implantace aortální chlopně CoreValve - první klinické zkušenosti u nemocných s vysokým operačním rizikem v IKEM. Cor Vasa 2009;51:773-780.

Došlo do redakce 22. 3. 2010

Prijato 20. 4. 2010 